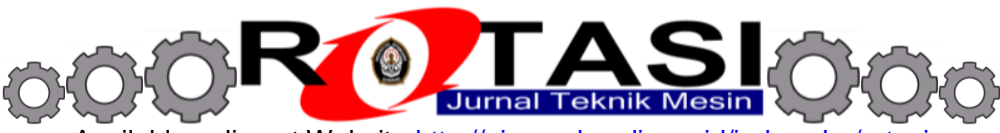

Available online at Website http://ejournal.undip.ac.id/index.php/rotasi

\section{STUDI EKSPERIMENTAL PENINGKATAN PERPINDAHAN PANAS ALIRAN TURBULEN PADA PENUKAR KALOR PIPA KONSENTRIK DENGAN PERFORATED TWISTED TAPE INSERT WITH PARALLEL WINGS}

\author{
*Indri Yaningsih, Tri Istanto, Wibawa Endra Juwana \\ Jurusan Teknik Mesin, Fakultas Teknik, Universitas Sebelas Maret \\ Jl. Ir. Sutami No 36A Kentingan Surakarta 57126 \\ *E-mail: indriyaningsih@staff.uns.ac.id
}

\begin{abstract}
Heat transfer, flow friction and thermal performance factor characteristics in a concentric pipe heat exchanger fitted perforated twisted tape insert with parallel wings (PTPW), using water as working fluid are investigated experimentally. The design of PTPW involves the following concepts: (1) wings induce an extra turbulence near tube wall and thus efficiently disrupt a thermal boundary layer (2) holes existing along a core tube, diminish pressure loss within the tube. The experiments are conducted using the PTPW with the three wing depth ratio $(w / W=0.16,0.24$ and 0.32$)$ and constant the hole diameter ratio $(d / W)$ of 0.24 over a Reynolds number range of 5800-18,500. A typical twisted tape insert (TT) was also tested for a comparison. The results show that both mean Nusselt number and mean friction factor associated by all twisted tape are consistently higher than those without twisted tape (plain tube). It is also found that Nusselt number, friction factor and thermal performance factor increase with increasing wing depth ratio. Over the range considered, Nusselt number and friction factor in a concentric pipe heat exchanger with the PTPW are, respectively, 1.14-1.42 and 1.12-1.40 times of those in the tube with typical twisted tape (TT).
\end{abstract}

Keywords: friction factor, hole diameter ratio, Nusselt number, thermal performance factor, wing depth ratio

\section{PENDAhUluan}

Peningkatan perpindahan panas adalah proses memperbaiki unjuk kerja sistem perpindahan panas dengan cara meningkatkan koefisien perpindahan panas. Pada dekade terakhir, teknologi peningkatan perpindahan panas telah dikembangkan dan diterapkan secara luas ke aplikasi penukar kalor; sebagai contoh: pendinginan (refrigeration), otomotif, industri kimia dan lain-lain. Sampai saat ini sejumlah besar usaha telah dilakukan untuk mengurangi ukuran dan biaya penukar kalor. Variabel yang paling signifikan dalam pengurangan ukuran dan biaya penukar kalor pada dasarnya adalah koefisien perpindahan panas dan penurunan tekanan (pressure drop). Teknologi peningkatan perpindahan panas hampir selalu meningkatkan penurunan tekanan, yang mempengaruhi biaya pemompaan lebih tinggi. Oleh karena itu metode peningkatan perpindahan panas yang digunakan dalam penukar kalor harus optimal antara keuntungan dari kenaikan koefisien perpindahan panas dan biaya pemompaan yang lebih tinggi karena meningkatnya kerugian gesekan.

Laju perpindahan panas dapat diperbaiki dengan memberikan gangguan pada aliran fluida (memecahkan viskos dan lapis batas termal), tetapi dalam prosesnya daya pemompaan (pumping power) dapat meningkat secara signifikan dan pada akhirnya biaya pemompaan menjadi tinggi. Oleh karena itu, untuk memperoleh laju perpindahan panas yang diinginkan dalam sebuah penukar kalor pada daya pemompaan yang ekonomis, beberapa teknik telah ditawarkan dalam tahun-tahun terakhir ini. Teknik peningkatan perpindahan panas dapat diklasifikasikan secara umum dalam tiga teknik utama: metode aktif, metode pasif dan metode campuran. Dalam metode aktif, perpindahan panas ditingkatkan dengan cara memberikan energi tambahan dari sumber luar. Pada sisi lain, metode pasif dapat dicapai tanpa sumber energi luar tetapi daya tambahan yang diperlukan untuk meningkatkan perpindahan panas dapat diambil dari daya yang tersedia dalam sistem. Dalam teknik campuran, dua atau lebih dari teknik aktif dan pasif digunakan secara simultan untuk menghasilkan peningkatan perpindahan panas, dimana peningkatan perpindahan panas lebih tinggi daripada jika teknik aktif dan teknik pasif dioperasikan secara terpisah [1]. Di antara teknik-teknik pasif, pemberian sisipan pada pipa (tube insert) adalah salah satu teknik yang paling menjanjikan.

Secara umum, beberapa jenis sisipan seperti twisted tapes, wire coils, ribs dan louvered strip insert ditempatkan dalam lintasan aliran untuk meningkatkan laju perpindahan panas. Aplikasi twisted tape dalam pipa penukar kalor adalah salah satu kunci teknik peningkatan perpindahan panas. Mekanisme umum dari peningkatan perpindahan panas dengan menggunakan twisted tape insert adalah menghasilkan aliran berputar, memperbaiki percampuran fluida dan dapat mengurangi tebal lapis batas termal. Twisted tape insert terbukti dapat meningkatkan perpindahan panas dalam sebuah penukar kalor, walau dengan mengorbankan penurunan tekanan yang besar. Penurunan tekanan ini sangat berpengaruh terhadap besarnya energi dari pompa yang digunakan untuk mengalirkan fluida tersebut atau yang biasa disebut dengan daya pemompaan. Sekarang banyak dilakukan modifikasi typical twisted tape insert yang bertujuan 
untuk mengurangi penurunan tekanan yang terjadi akibat penambahan twisted tape insert, atau untuk lebih menaikkan perpindahan panas yang terjadi dalam sebuah penukar kalor. Salah satu cara untuk mengurangi penurunan tekanan adalah dengan pemberian lubang-lubang kecil di twisted tape yang disebut dengan perforated twisted tape insert [2-7]. Pemberian lubang-lubang ini bertujuan untuk mengurangi efek halangan (blocking effect) aliran dari dinding twisted tape insert. Modifikasi typical twisted tape insert untuk lebih dapat meningkatkan perpindahan panas salah satunya dengan memberikan sayap-sayap (wings) di sepanjang garis tengah twisted tape (center wings) atau di sepanjang tepi twisted tape [8-11]. Desain twisted tape yang diinginkan adalah twisted tape dapat menghasilkan kenaikan perpindahan panas yang baik dengan kenaikan gesekan yang minimum.

Berhubungan dengan keperluan di atas, pada penelitian ini dibuat desain baru twisted tape insert yang disebut perforated twisted tape insert with parallel wings (PTPW). Desain dari PTPW meliputi konsep sebagai berikut: (1) sayap-sayap (wings) menimbulkan sebuah turbulensi tambahan di dekat dinding pipa dan kemudian mengganggu secara efisien lapis batas termal (2) lubang-lubang yang ada di sepanjang garis tengah twisted tape, mengurangi kehilangan tekanan di dalam pipa. Untuk mengevaluasi aplikasi praktis, unjuk kerja energi menyeluruh dalam parameter faktor unjuk kerja termal dievaluasi padadaya pemompaan yang sama. Penelitian dilakukan untuk aliran berkembang penuh dalam daerah turbulen $(5800 \leq \operatorname{Re} \leq 18.500)$.

\section{MATERIAL DAN METODOLOGI}

Skema diagram alat penelitian ditunjukkan pada Gambar 1. Lintasan uji terdiri dari seksi uji, lintasan air panas, lintasan air dingin dan sistem pengukuran data. Seksi uji berupa penukar kalor pipa konsentrik dengan twisted tape insert di dalamnya. Penukar kalor pipa konsentrik terbuat dari pipa aluminium lurus yang terdiri dari pipa dalam (inner tube) dan pipa luar (outer tube). Dimensi dari pipa dalam dan pipa luar adalah sebagai berikut: $\mathrm{d}_{\mathrm{i}}=14,3 \mathrm{~mm}, \mathrm{~d}_{\mathrm{o}}=15,8$ $\mathrm{mm}, \mathrm{L}_{\mathrm{i}}=2500 \mathrm{~mm}, \mathrm{D}_{\mathrm{i}}=23,4 \mathrm{~mm}, \mathrm{D}_{\mathrm{o}}=25,4 \mathrm{~mm}$ and $\mathrm{L}_{\mathrm{o}}=1950 \mathrm{~mm}$. Pengujian dilakukan dengan arah penukar kalor mendatar. Air panas mengalir melalui pipa dalam, sedangkan air dingin mengalir melalui annulus. Temperatur masukan air panas melalui pipa dalam dijaga konstan $60^{\circ} \mathrm{C}$, sedangkan temperatur masukan air dingin di annulus adalah $\pm 28^{\circ} \mathrm{C}$. Panjang pengukuran beda tekanan di pipa dalam adalah $2.240 \mathrm{~mm}$.

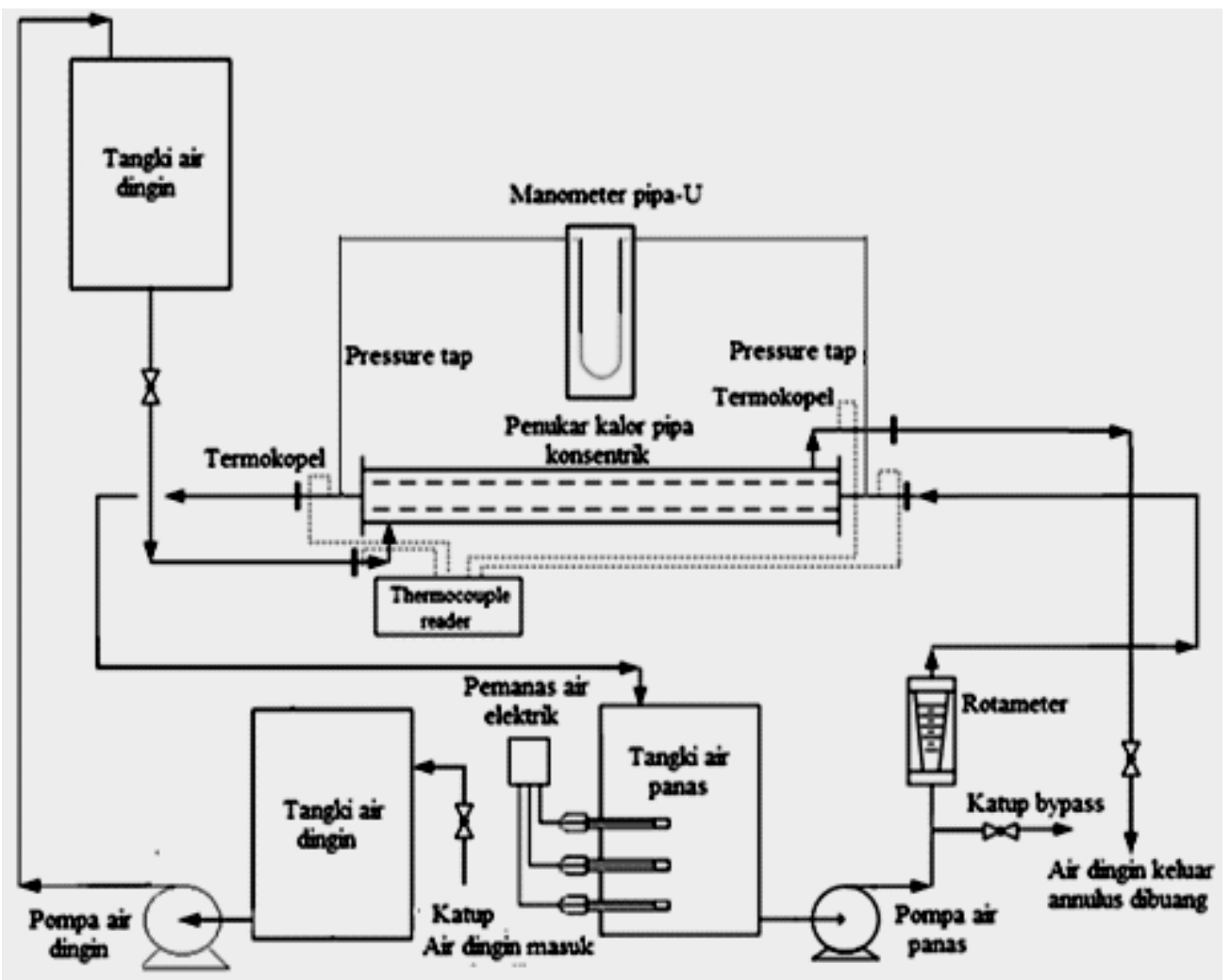

Gambar 1. Skema diagram alat penelitian

Dalam penelitian ini dimaksudkan untuk mencari perubahan koefisien perpindahan panas konveksi aliran turbulen sisi pipa dalam dengan mempengaruhi daerah dekat dinding pipa. Untuk tujuan ini, perforated twisted tape insert with paralel wings (PTPW) dipasang di sisi pipa dalam dari penukar kalor pipa konsentrik sebagai sebuah turbulator. Untuk perbandingan, dalam penelitian ini juga diuji pipa dalam tanpa sisipan (plain tube) dan dengan typical twisted tape insert (TT). Temperatur masuk dan keluar fluida (air panas dan air dingin) dan temperatur pada 10 titik dinding luar pipa dalam diukur dengan menggunakan termokopel tipe-K. Temperatur-temperatur dibaca dengan 
menggunakan sebuah multi-channel thermocouple reader. Laju aliran air panas di pipa dalam diukur dengan rotameter. Penelitian dilakukan dengan memvariasi laju aliran massa air panas di pipa dalam dari 0,033 kg/s-0,099 kg/s (bilangan Reynolds berkisar 5800-18.500) sedangkan laju aliran massa air dingin di annulus dijaga konstan sebesar $0,103 \mathrm{~kg} / \mathrm{s}$. Temperatur air panas masukan ke pipa dalam dijaga konstan $60^{\circ} \mathrm{C}$, dengan menggunakan pemanas air elektrik yang dikontrol dengan thermocontroller.Penurunan tekanan di sisi pipa dalam diukur dengan menggunakan manometer pipaU yang diisi dengan air. Data yang dipakai untuk analisa adalah data pada saat penukar kalor mencapai kondisi tunak.

TT terbuat dari bahan aluminium strip dengan tebal $(\delta) 0,7 \mathrm{~mm}$, lebar $(W)$ 12,6 $\mathrm{mm}$ dan panjang $2000 \mathrm{~mm}$ yang dipuntir sedemikian rupa sehingga berbentuk sebuah pilinan yang mempunyai panjang pitch (y) 48 mm dan twist ratio $(y / W)$ sebesar 3,8. PTPW terbuat dari bahan dan ukuran yang sama dengan TT dengan nilai pitch dan twist ratio dijaga konstan berturut-turut $48 \mathrm{~mm}$ dan 3,8. PTPW adalah modifikasi dari TT dengan cara membuat lubang-lubang di sepanjang garis tengah twisted tape dalam garis lurus pada setiap panjang pitch. Kemudian untuk setiap tape dipotong pada tepi dari kedua sisi tape diantara lubang-lubang yang berurutan, sesudah itu masing-masing potongan ditekuk $45^{\circ}$ ke aliran aksial dalam arah yang sama, sehingga disebut dengan parallel-wings. PTPW divariasi nilai wing depth ratio $(w / W)$ sebesar 0,$16 ; 0,24$ dan 0,32 , sedangkan hole diameter ratio $(d / W)$ dibuat sama yaitu 0,24 dengan jarak antar pusat lubang sebesar $48 \mathrm{~mm}$. TT dan PTPW yang digunakan dalam penelitian ini dapat dilihat pada Gambar 2.

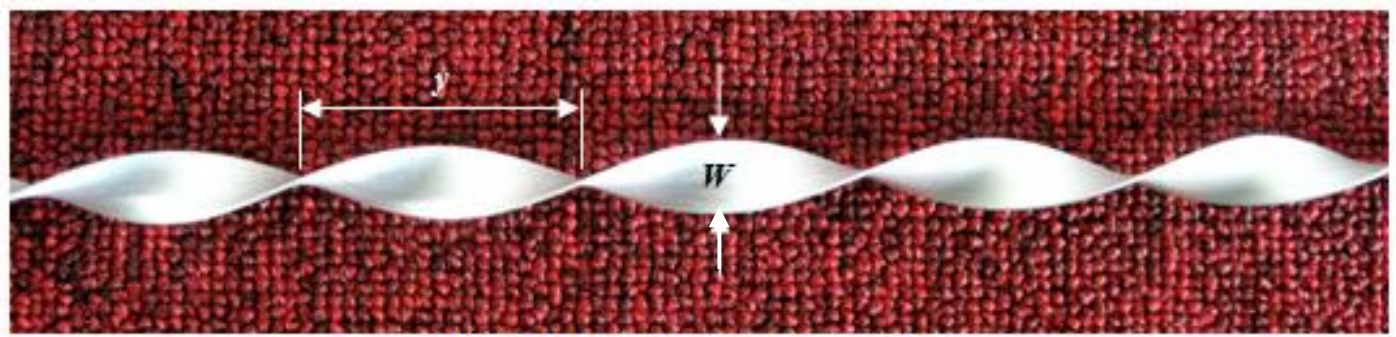

(a) Typical twisted tape insert (TT)
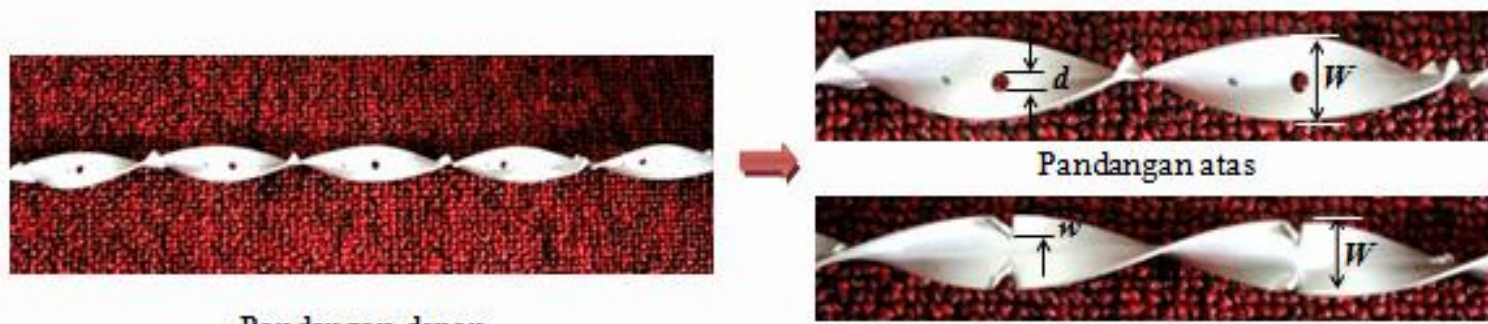

Pandangan depan

(b) Perforated twisted tape insert with parallel wings (PTPW)

Gambar 2. TT dan PTPW yang digunakan dalam penelitian

Data eksperimen digunakan untuk menghitung bilangan Nusselt, faktor gesekan dan faktor unjuk kerja termal pada bilangan Reynolds (Re) yang berbeda dalam daerah aliran turbulen di sisi pipa dalam untuk kasus plain tube dan dengan menggunakan TT dan PTPW. Langkah pertama, laju perpindahan panas dari air panas di pipa dalam dapat dinyatakan sebagai berikut:

$$
Q_{h}=\dot{m} \cdot C_{p, h} \cdot\left(T_{h, i}-T_{h, o}\right)=U_{i} \cdot A_{i} \cdot \Delta T_{L M T D}
$$

Pada sisi yang lain, perpindahan panas ke air dingin di sisi annulus dapat dihitung dengan:

$$
Q_{c}=\dot{m} \cdot C_{p, c} \cdot\left(T_{c, o}-T_{c, i}\right)=h_{o} \cdot A_{o} \cdot\left(\bar{T}_{w, o}-T_{b, o}\right)
$$

dimana

$$
T_{b, o}=\frac{T_{c, i}+T_{c, o}}{2} \text { dan } \bar{T}_{w, o}=\frac{\sum T_{w, o}}{10}
$$


$\bar{T}_{w, o}$ adalah temperatur rata-rata dari dinding luar pipa dalam, dimana adalah rata-rata aritmetika dari 10 titik pengukuran temperatur dinding luar pipa dalam. $\mathrm{T}_{\mathrm{b}, \mathrm{o}}$ adalah temperatur bulk rata-rata air dingin dimana dihitung dari temperatur rata-rata air dingin masuk dan keluar annulus. Perbedaan antara dua laju perpindahan panas ini menunjukkan kehilangan panas dari penukar kalor, dimana dapat diasumsikan diabaikan dalam penelitian ini:

$$
Q_{\text {loss }}=Q_{h}-Q_{\mathrm{c}}
$$

Kehilangan panas melalui isolasi dapat dihitung dan diperkirakan $<5 \%$ dari total panas yang disuplai. Laju perpindahan panas rata-rata, $Q_{a v e}$ digunakan dalam perhitungan ditentukan dari sisi air panas dan sisi air dingin sebagai berikut:

$$
Q_{\text {ave }}=\frac{Q_{h}+Q_{c}}{2}
$$

Koefisien perpindahan panas menyeluruh di pipa dalam, $\mathrm{U}_{\mathrm{i}}$, dapat ditentukan dari:

$$
Q_{\text {ave }}=U_{i} \cdot A_{i} \cdot \Delta T_{L M T D}
$$

Koefisien perpindahan panas konveksi rata-rata di pipa dalam, $\mathrm{h}_{\mathrm{i}}$ didapatkan dari tahanan termal total yang terdiri dari tiga tahanan dalam susunan seri; tahanan termal konveksi pada pipa dalam, tahanan termal konduksi dari dinding pipa dalam dan tahanan termal konveksi pada sisi annulus.

$$
\frac{1}{U_{i} \cdot A_{1}}=\frac{1}{h_{i} \cdot A_{i}}+\frac{\ln \left(d_{o} / d_{i}\right)}{2 \pi k_{p} L}+\frac{1}{h_{o} \cdot A_{o}}
$$

Sehingga $h_{i}$ dapat dihitung dari persamaan (7) sebagai berikut:

$$
h_{i}=\frac{1}{\left[\frac{1}{U_{i}}-\frac{d_{i} \cdot \ln \left(d_{o} / d_{i}\right)}{2 k_{p}}-\frac{d_{i}}{d_{o} \cdot h_{o}}\right]}
$$

Bilangan Nusselt rata-rata di sisi pipa dalam diperoleh dari koefisien perpindahan konveksi rata-rata di pipa dalam sebagai berikut:

$$
N u_{i}=\frac{h_{i} \cdot d_{i}}{k_{i}}
$$

Faktor gesekan di pipa dalam, $f$, dapat dihitung dari:

$$
f=\frac{\Delta P}{\left(\rho u^{2} / 2\right)\left(L / d_{i}\right)}
$$

Bilangan Reynolds (Re) aliran turbulen di pipa dalam dihitung dengan:

$$
\operatorname{Re}=\frac{\rho . u \cdot d_{i}}{\mu}
$$

Semua sifat-sifat termofisik fluida air ditentukan berdasarkan temperatur fluida bulk rata-rata $\left(\mathrm{T}_{\mathrm{b}}\right)$.

Indeks peningkatan perpindahan panas atau faktor unjuk kerja termal adalah salah satu parameter kunci dalam desain penukar kalor. Salah satu metode untuk mengevaluasi potensi aplikasi praktis dari dari twisted tape adalah membandingkan koefisien perpindahan panas konveksi dalam sebuah pipa yang dilengkapi dengan sebuah twisted tape dengan plain tube di bawah kondisi daya pemompaan yang sama. Untuk daya pemompaan yang konstan [13] 


$$
(\dot{V} . \Delta P)_{p}=(\dot{V} \cdot \Delta P)_{t}
$$

dan hubungan antara gesekan dan bilangan Reynolds untuk plain tube dan pipa dalam dengan penambahan PTPW dapat dinyatakan sebagai berikut:

$$
\left(f \cdot \operatorname{Re}^{3}\right)_{p}=\left(f \cdot \operatorname{Re}^{3}\right)_{t}
$$

Faktor unjuk kerja termal $(\eta)$ pada daya pemompaan yang konstan adalah perbandingan koefisien perpindahan panas konveksi dari pipa dalam dengan penambahan PTPW dengan plain tube dimana dapat ditulis sebagai berikut:

$$
\eta=\left.\frac{h_{t}}{h_{p}}\right|_{p p}
$$

Kombinasi persamaan (12) - (14) menghasilkan:

$$
\eta=\left(N u_{t} / N u_{p}\right) /\left(f_{t} / f_{p}\right)^{1 / 3}
$$

Faktor unjuk kerja termal, menunjukkan keuntungan praktis dari penggunaan PTPW yang diperoleh dari persamaan (15), dimana laju perpindahan panas dan faktor gesekan dalam pipa dengan dan tanpa PTPW secara simultan ditentukan pada daya pemompaan yang sama.

\section{HASIL DAN PEMBAHASAN}

\subsection{Validasi Hasil Eksperimen}

Karakteristik perpindahan panas dan faktor gesekan plain tube yang diperoleh dari hasil eksperimen diverifikasi dalam terminologi bilangan Nusselt $(\mathrm{Nu})$ dan faktor gesekan $(f)$. Bilangan Nusselt dan faktor gesekan plain tube dibandingkan dengan korelasi -korelasi dari Petukhov (1970) dan Gnielinski (1976) untuk bilangan Nusselt dan korelasi Blasius [12] untuk faktor gesekan. Gambar 3 dan 4 menunjukkan perbandingan bilangan Nusselt dan faktor gesekan plain tube yang diperoleh dari penelitian dengan korelasi-korelasi empirik Petukhov, Gnielinski dan Blasius.

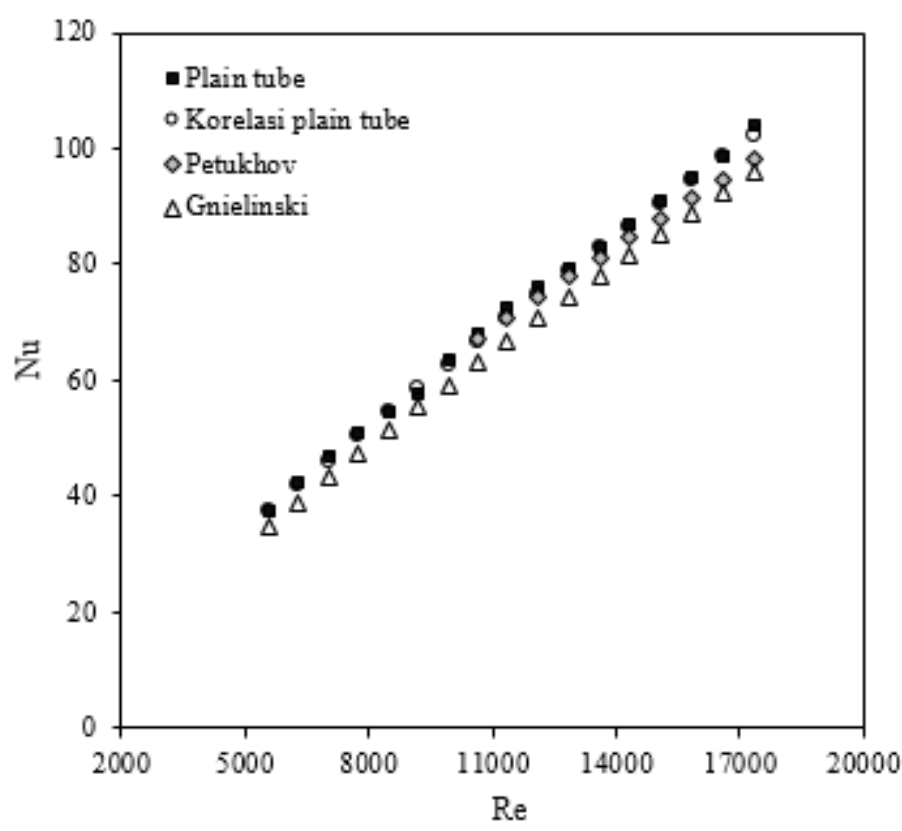

Gambar 3. Validasi bilangan Nusselt untuk plain tube

Bilangan Nusselt yang diperoleh dari eksperimen untuk plain tube sesuai dengan hasil prediksi dari korelasi Petukhov dan Gnielinski dengan ketidaksesuaian berturut-turut kurang dari $\pm 3,05 \%$ dan $\pm 6,86 \%$. Faktor gesekan plain tube sesuai dengan hasil prediksi dari korelasi Blasius dengan ketidaksesuaian kurang dari $\pm 1,67 \%$. Hasil eksperimen untuk plain tube dibuat korelasi-korelasi untuk bilangan Nusselt dan faktor gesekan sebagai berikut: 


$$
\begin{aligned}
& \mathrm{Nu}=0,012 \cdot \operatorname{Re}^{0,8} \cdot \operatorname{Pr}^{0,3} \\
& f=0,394 \cdot \operatorname{Re}^{-0,272}
\end{aligned}
$$

Persamaan (16) dan (17) didapatkan mewakili data eksperimen tidak lebih dari $\pm 2,75 \%$ untuk bilangan Nusselt dan $\pm 2,14 \%$ untuk faktor gesekan, seperti digambarkan berturut-turut dalam Gambar 3 dan 4 .

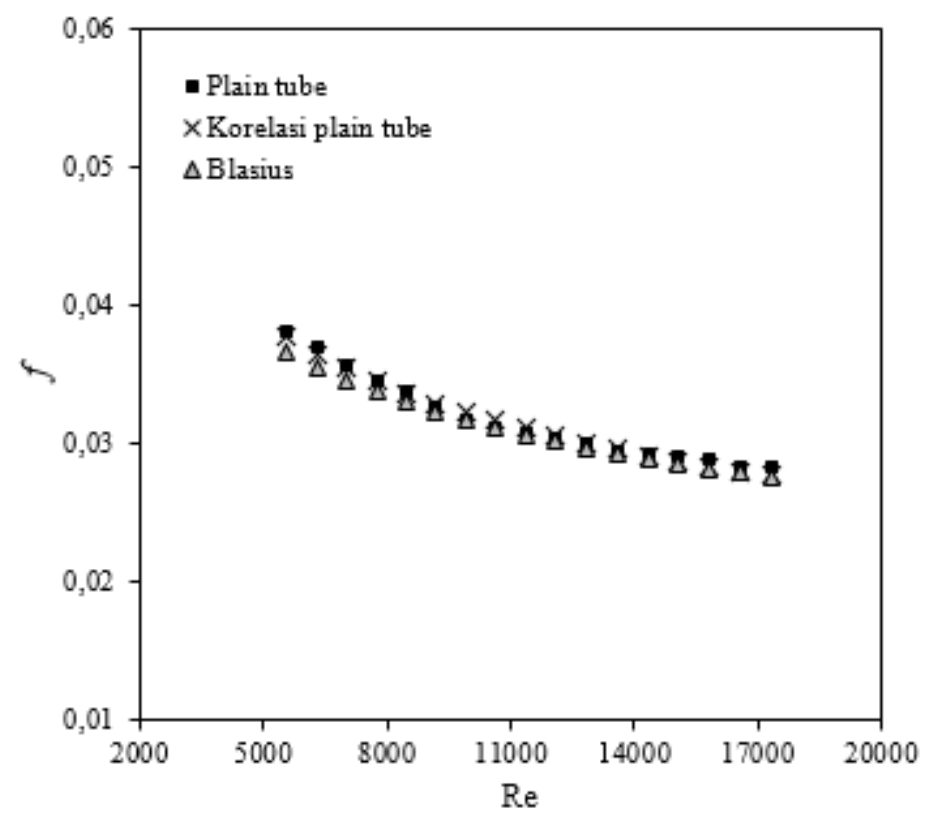

Gambar 4. Validasi faktor gesekan untuk plain tube.

\subsection{Pengaruh Wing Depth Ratio Terhadap Karakteristik Perpindahan Panas.}

Pengaruh wing depth ratio $(w / W=0,16 ; 0,24$ dan 0,32$)$ terhadap karakteristik perpindahan panas dapat dilihat pada Gambar 5.

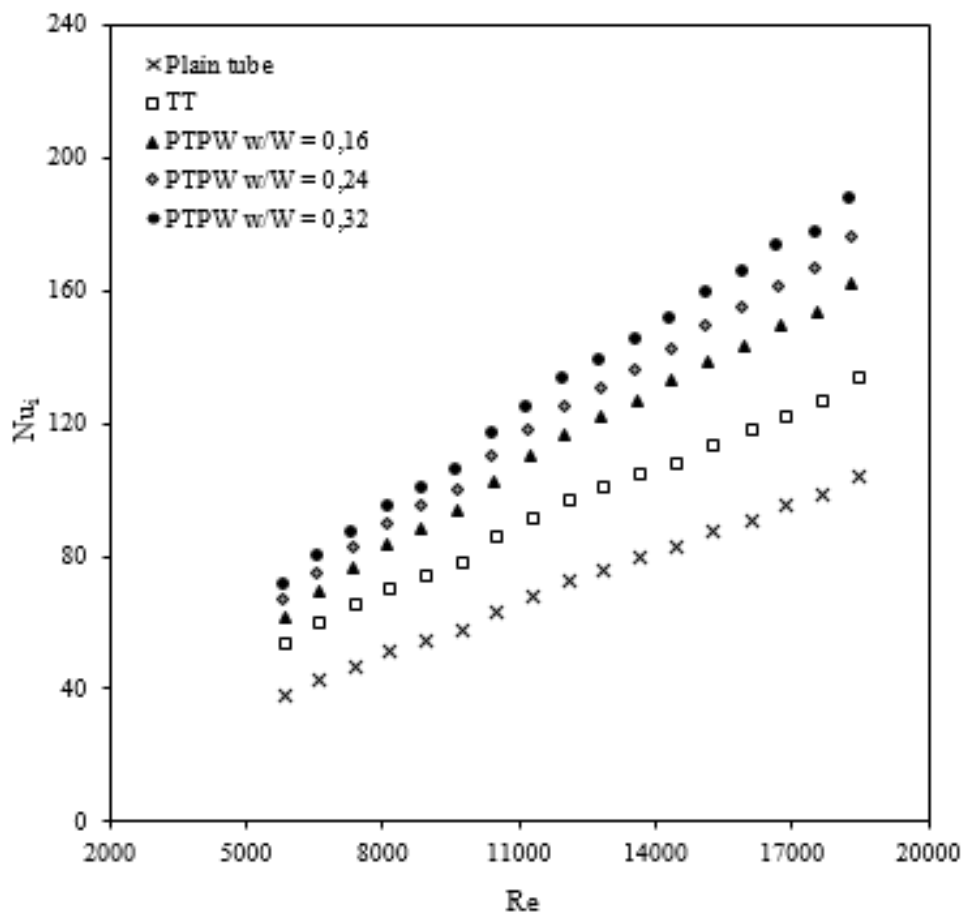

Gambar 5. Hubungan $\mathrm{Nu}_{\mathrm{i}}$ dengan $\mathrm{Re}$

Dari Gambar 5 terlihat bahwa dengan kenaikan bilangan Reynolds (Re), maka bilangan Nusselt rata-rata di pipa dalam $\left(\mathrm{Nu}_{\mathrm{i}}\right)$ semakin naik. Kenaikan bilangan Nusselt rata-rata di pipa dalam berarti terjadi kenaikan perpindahan panas 
di pipa dalam dari penukar kalor pipa konsentrik. Kenaikan bilangan Nusselt rata-rata di pipa dalam menunjukkan kenaikan koefisien perpindahan panas konveksi rata-rata di pipa dalam $\left(h_{i}\right)$. Hal ini terjadi untuk plain tube maupun untuk pipa dalam dengan penambahan sisipan TT dan PTPW untuk semua variasi $w / W$.

Desain PTPW meliputi konsep sebagai berikut: (1) sayap-sayap (wings) menyebabkan turbulensi tambahan di dekat dinding pipa dan kemudian secara efisien memecah lapis batas termal, (2) lubang-lubang yang ada sepanjang pusat pipa, mengurangi kehilangan tekanan di dalam pipa. Dari gambar 5 pengaruh keberadaan wings terhadap perpindahan panas adalah signifikan, tampak jelas sekali dengan nilai bilangan Nusselt rata-rata di pipa dalam yang lebih tinggi karena penambahan sisipan PTPW dibandingkan dengan penambahan sisipan TT. Perpindahan panas yang lebih tinggi ini diakibatkan oleh aliran turbulen tambahan di dekat dinding pipa, dimana secara efisien mengganggu lapis batas termal dengan memecah lapis batas viskos secara periodik [11]. Dari gambar 5 dapat dilihat bahwa bilangan Nusselt meningkat dengan kenaikan wing depth ratio $(w / W)$. Ini dapat dijelaskan bahwa dengan semakin besar nilai $w / W$ menyebabkan intensitas turbulensi yang lebih tinggi dan kemudian percampuran fluida yang lebih baik di dekat dinding pipa [11].

Pada kisaran bilangan Reynolds 5800 - 18.500, pipa dalam dengan penambahan sisipan TT, kenaikan bilangan Nusselt di pipa dalam rata-rata $33,8 \%$ dibandingkan dengan plain tube. Sedangkan pada pipa dalam dengan penambahan sisipan PTPW variasi $w / W=0,16 ; 0,24$ dan 0,32 bilangan Nusselt di pipa dalam meningkat rata-rata berturut-turut sebesar $60,5 \%, 72,8 \%$ dan $84,5 \%$ jika dibandingkan dengan plain tube. Jika dibandingkan dengan penambahan sisipan TT, pipa dalam dengan penambahan sisipan PTPW mengalami kenaikan bilangan Nusselt rata-rata dalam kisaran $15 \%-23 \%, 24-32 \%$ dan $33-42 \%$ berturut-turut untuk variasi $w / W=0,16 ; 0,24$ dan 0,32 .

\subsection{Pengaruh Wing Depth Ratio Terhadap Karakteristik Faktor Gesekan}

Pengaruh wing depth ratio $(w / W=0,16 ; 0,24$ dan 0,32$)$ terhadap karakteristik faktor gesekan dapat dilihat pada gambar 6. Dengan kenaikan bilangan Reynolds, nilai faktor gesekan di pipa dalam dari penukar kalor pipa konsentrik semakin berkurang. Hal ini terjadi untuk plain tube maupun untuk pipa dalam dengan penambahan sisipan TT dan PTPW.

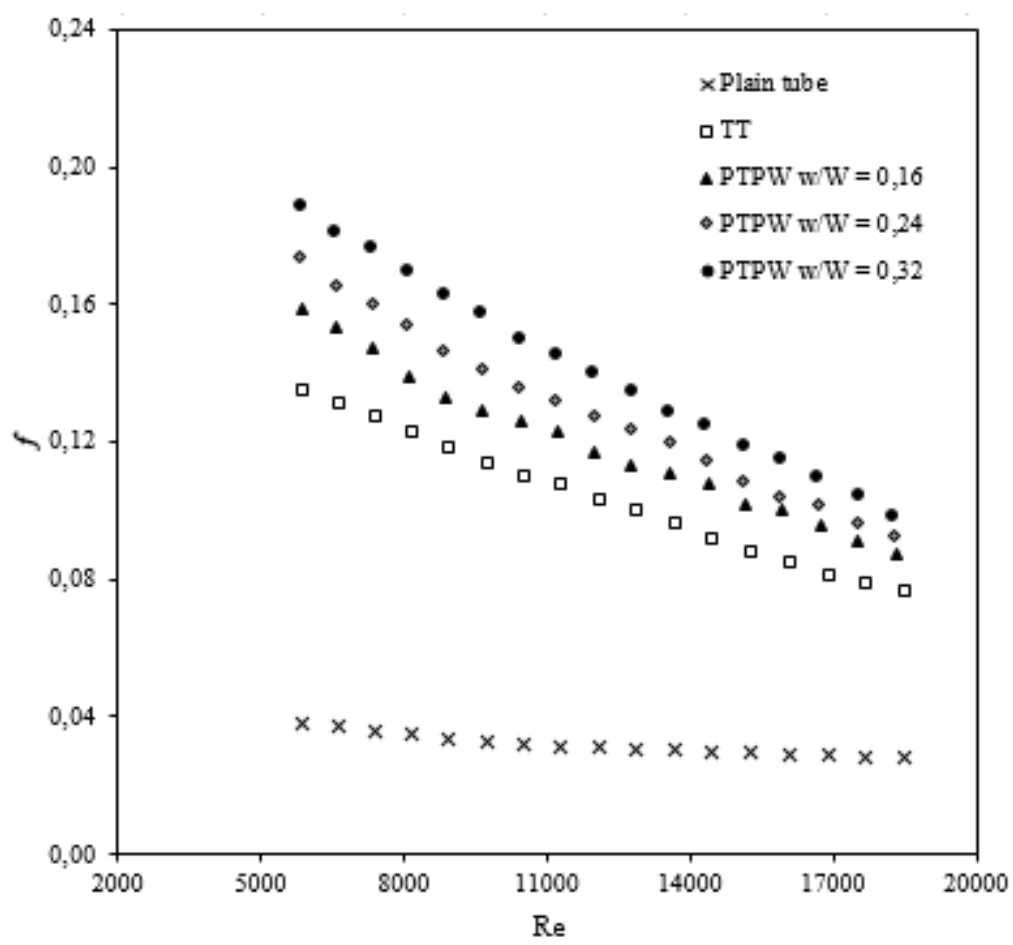

Gambar 6. Hubungan $f$ dengan Re

Dari gambar 6 dapat dilihat bahwa nilai faktor gesekan pipa dalam dengan penambahan sisipan TT dan PTPW lebih besar dibandingkan faktor gesekan plain tube. Penambahan sisipan PTPW di pipa dalam dengan nilai $w / W$ yang semakin besar menyebabkan faktor gesekan pipa dalam yang semakin tinggi. Hal ini berhubungan langsung dengan intensitas turbulensi yang semakin tinggi dengan penambahan sisipan PTPW pada nilai $w / W$ yang semakin besar. Pada kisaran bilangan Reynolds 5800 - 18.500, penambahan sisipan PTPW dengan variasi $w / W=0,16,0,24$ dan 0,32 nilai faktor gesekan pipa dalam meningkat berturut-turut rata-rata 1,15; 1,24 dan 1,36 kali lebih tinggi daripada penambahan sisipan TT.

\subsection{Pengaruh Wing Depth Ratio Terhadap Karakteristik Unjuk Kerja Termal}


Pengaruh wing depth ratio $(w / W=0,16 ; 0,24$ dan 0,32$)$ terhadap karakteristik faktor unjuk kerja termal ( $\eta)$ dapat dilihat pada gambar 7. Penambahan sisipan PTPW di pipa dalam menghasilkan faktor unjuk kerja termal yang lebih besar dibandingkan penambahan sisipan TT untuk semua variasi $w / W$. Pada penambahan sisipan PTPW, faktor unjuk kerja termal meningkat dengan kenaikan $w / W$. Nilai faktor unjuk kerja termal pipa dalam dengan penambahan sisipan TT dan PTPW dengan variasi $w / W=0,16 ; 0,24$ dan 0,32 berturut-turut dalam kisaran $1,00-1,24 ; 1,16-1,36 ; 1,21-1,41$ dan 1,25-1,45. Ini menunjukkan bahwa pada daya pemompaan yang sama, nilai koefisien perpindahan panas konveksi rata-rata dari pipa dalam dengan penambahan sisipan PTPW dengan variasi $w / W=0,16,0,24$ dan 0,32 lebih besar dari nilai koefisien perpindahan panas konveksi rata-rata dari sisipan TT.

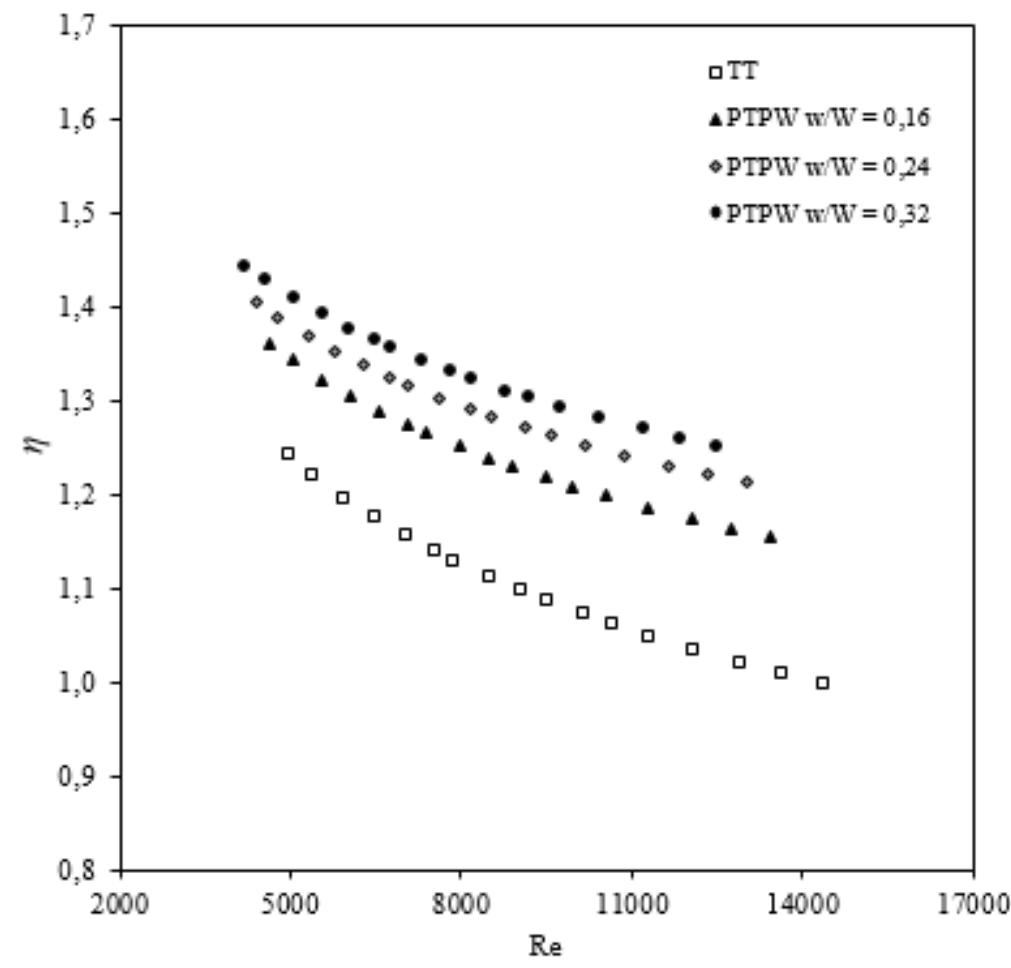

Gambar 7. Hubungan $\eta$ dengan Re

\section{KESIMPULAN}

Pada bilangan Reynolds 5800-18.500, bilangan Nusselt dan faktor gesekan penukar kalor pipa konsentrik dengan penambahan sisipan PTPW variasi $w / W=0,16,0,24$ dan 0,32 secara konsisten lebih besar dibandingkan dengan penambahan TT dan plain tube. Nilai bilangan Nusselt, faktor gesekan dan faktor unjuk kerja termal semakin tinggi dengan kenaikan nilai $w / W$. Bilangan Nusselt rata-rata pipa dalam dengan penambahan PTPW dengan variasi $w / W=$ 0,16, 0,24 dan 0,32 berturut-turut meningkat dalam kisaran 15\%-23\%, 24-32\% dan 33-42\% dibandingkan dengan penambahan TT. Penambahan sisipan PTPW dengan variasi $w / W=0,16,0,24$ dan 0,32 di pipa dalam menghasilkan faktor gesekan rata-rata berturut-turut sebesar 1,$15 ; 1,24$ dan 1,36 kali faktor gesekan TT. Unjuk kerja termal rata-rata dengan penambahan TT dan PTPW variasi $w / W=0,16,0,24$ dan 0,32 di pipa dalam berturut-turut dalam kisaran 1,001,$24 ; 1,16-1,36 ; 1,21-1,41$ dan $1,25-1,45$.

\section{DAFTAR NOTASI}

$\mathrm{A}_{\mathrm{i}} \quad$ luas permukaan dalam pipa dalam $\left(\mathrm{m}^{2}\right)$

$\mathrm{A}_{\mathrm{o}} \quad$ luas permukaan luar pipa dalam $\left(\mathrm{m}^{2}\right)$

$\mathrm{Cp}, \mathrm{c} \quad$ panas jenis air dingin di annulus $\left(\mathrm{kJ} / \mathrm{kg} .{ }^{\circ} \mathrm{C}\right)$

$\mathrm{Cp}, \mathrm{h} \quad$ panas jenis air panas di pipa dalam $\left(\mathrm{kJ} / \mathrm{kg} .{ }^{\circ} \mathrm{C}\right)$

$\mathrm{d}_{\mathrm{i}} \quad$ diameter dalam pipa dalam $(\mathrm{m})$

$\mathrm{d}_{\mathrm{o}} \quad$ diameter luar pipa dalam $(\mathrm{m})$

$\mathrm{D}_{\mathrm{i}} \quad$ diameter dalam pipa luar $(\mathrm{m})$

$\mathrm{D}_{\mathrm{o}} \quad$ diameter luar pipa luar $(\mathrm{m})$

$f \quad$ faktor gesekan

$f_{p} \quad$ faktor gesekan plain tube

$f_{t} \quad$ faktor gesekan pipa dalam dengan twisted tape insert

$\mathrm{h}_{\mathrm{i}} \quad$ koefisien perpindahan panas konveksi rata-rata di pipa dalam $\left(\mathrm{W} / \mathrm{m}^{2} .{ }^{\circ} \mathrm{C}\right)$

$\mathrm{h}_{\mathrm{o}} \quad$ koefisien perpindahan panas konveksi rata-rata di annulus $\left(\mathrm{W} / \mathrm{m}^{2} .{ }^{\circ} \mathrm{C}\right)$ 
$\mathrm{h}_{\mathrm{p}} \quad$ koefisien perpindahan panas konveksi rata-rata di plain tube $\left(\mathrm{W} / \mathrm{m}^{2} .{ }^{\circ} \mathrm{C}\right)$

$\mathrm{h}_{\mathrm{s}}$

$\mathrm{k}_{\mathrm{i}}$

$\mathrm{k}_{\mathrm{p}}$

$\mathrm{L}$

$\dot{\mathrm{m}}_{\mathrm{c}}$

$\dot{\mathrm{m}}_{\mathrm{h}}$

$\mathrm{Nu}_{\mathrm{i}}$

$\mathrm{Nu}_{\mathrm{p}}$

$\mathrm{Nu}_{\mathrm{t}}$

Pr

$Q_{\mathrm{c}}$

$Q_{\mathrm{h}}$

$Q_{\text {loss }}$

$\operatorname{Re}$

$\mathrm{T}_{\mathrm{b}, \mathrm{o}}$

$\mathrm{T}_{\mathrm{c}, \mathrm{i}}$

$\mathrm{T}_{\mathrm{c}, \mathrm{o}}$

$\mathrm{T}_{\mathrm{h}, \mathrm{i}}$

$\mathrm{T}_{\mathrm{h}, \mathrm{o}}$

$\bar{T}_{w, o}$

$\delta$

$\mathrm{U}_{\mathrm{i}}$

V

V

$y$

$\rho$

$\eta$

$\mu$

$\Delta \mathrm{P}$

$\Delta \mathrm{T}_{\mathrm{LMTD}}$

koefisien perpindahan panas konveksi rata-rata di pipa dalam dengan twisted tape insert $\left(\mathrm{W} / \mathrm{m}^{2} .^{\circ} \mathrm{C}\right)$

konduktivitas termal rata-rata air panas di pipa dalam $\left(\mathrm{W} / \mathrm{m} .{ }^{\circ} \mathrm{C}\right)$

konduktivitas termal material pipa dalam $\left(\mathrm{W} / \mathrm{m} .{ }^{\circ} \mathrm{C}\right)$

panjang pipa (m)

laju aliran massa air dingin di annulus $(\mathrm{kg} / \mathrm{s})$

laju aliran massa air panas di pipa dalam $(\mathrm{kg} / \mathrm{s})$

bilangan Nusselt rata-rata di pipa dalam

bilangan Nusselt rata-rata di plain tube

bilangan Nusselt rata-rata di pipa dalam dengan twisted tape insert

bilangan Prandtl

laju perpindahan panas di annulus (W)

laju perpindahan panas di pipa dalam (W)

kehilangan panas konveksi di pipa dalam (W)

bilangan Reynolds

temperatur bulk rata-rata di annulus $\left({ }^{\circ} \mathrm{C}\right)$

temperatur air dingin masuk annulus $\left({ }^{\circ} \mathrm{C}\right)$

temperatur air dingin keluar annulus $\left({ }^{\circ} \mathrm{C}\right)$

temperatur air panas masuk pipa dalam $\left({ }^{\circ} \mathrm{C}\right)$

temperatur air panas keluar pipa dalam $\left({ }^{\circ} \mathrm{C}\right)$

temperatur rata-rata dinding luar pipa dalam $\left({ }^{\circ} \mathrm{C}\right)$

tebal twisted tape $(\mathrm{m})$

koefisien perpindahan panas menyeluruh berdasarkan permukaan dalam pipa dalam $\left(\mathrm{W} / \mathrm{m}^{2} .{ }^{\circ} \mathrm{C}\right)$

kecepatan rata-rata air panas di pipa dalam $(\mathrm{m} / \mathrm{s})$

laju aliran volumetrik air panas di pipa dalam $\left(\mathrm{m}^{3} / \mathrm{s}\right)$

panjang twist $(\mathrm{m})$

densitas air panas di pipa dalam $\left(\mathrm{kg} / \mathrm{m}^{3}\right)$

faktor unjuk kerja termal

viskositas dinamik air panas di pipa dalam $(\mathrm{kg} / \mathrm{m} . \mathrm{s})$

penurunan tekanan $(\mathrm{Pa})$

beda temperatur rata-rata logaritmik $\left({ }^{\circ} \mathrm{C}\right)$

\section{REFERENSI}

[1] Dewan, A., Mahanta, P., Sumithra Raju, K., Suresh Kumar, P., 2004, "Review of passive heat transfer augmentation techniques", Proceedings of the Institution of Mechanical Engineers Part A: Journal of Power and Energy, 218: 509-527.

[2] Ahamed, J.U., Rashid Sarkar, M.A., Khan, M.H, Wazed, M.A., 2007, "Heat transfer in turbulent flow through tube with perforated twisted tape insert", Proceedings of the International Conference on Mechanical Engineering (ICME2007) 29-31 Desember 2007, Dhaka, Bangladesh.

[3] Rahimi, M., Shabaniana, S.R., Alsairafi, A.A., 2009, "Experimental and CFD studies on heat transfer and friction factor characteristics of a tube equipped with modified twisted tape inserts", Chemical Engineering and Processing: Process Intensification, 48: 762-770.

[4] Ahamed, J.U., Bhuiya, M.M.K., Saidur, R., Masjuki, H.H., Sarkar, M.A.R, Sayem, A.S.M., and Islam, M., 2010, "Forced convection heat transfer performance of porous twisted tape insert", Engineering e-Transaction, 5: 67-79

[5] Thianpong, C., Eiamsa-ard, P., Eiamsa-ard,S., 2011, "Heat transfer and thermal performance characteristics of heat exchanger tube fitted with perforated twisted-tapes", Heat Mass Transfer, 48: 881-892.

[6] Ahamed, J.U., Wazed, M.A., Ahmed, S., Nukman, Y., Tuan Ya, T.M.Y.S., Sarkar, M.A.R., Khan, M.H, 2011, "Enhancement and prediction of heat transfer rate in turbulent flow through tube with perforated twisted tape inserts: A new correlation", Journal of Heat Transfer, 133: 041903-1- 041903-9

[7] Bhuiya, M.M.K., Chowdhury, M.S.U., Saha, M., Islam, M.T., 2013, "Heat transfer and friction factor characteristics in turbulent flow through a tube fitted with perforated twisted tape inserts", International Communications in Heat and Mass Transfer, 46: 49-57

[8] Eiamsa-ard, S., Wongcharee, K., Eiamsa-ard, P., Thianpong, C., 2010, "Thermohydraulic investigation of turbulent flow through a round tube equipped with twisted tapes consisting of centre wings and alternate-axes", Experimental Thermal and Fluid Science, 34: 1151-1161.

[9] Eiamsa-ard,S., Wongcharee, K., Eiamsa-ard, P., Thianpong, C., 2010, "Heat transfer enhancement in a tube using delta-winglet twisted tape inserts", Applied Thermal Engineering, 30: 310-318. 
[10] Wongcharee, K., Eiamsa-ard,S., Thianpong, C., 2011, "Heat transfer enhancement by twisted tapes with alternate-axes and triangular, rectangular and trapezoidal wings", Chemical Engineering and Processing: Process Intensification, 50: 211-219.

[11] Thianpong, C., Eiamsa-ard, P., Promvonge, P., Eimsa-ard, S., 2012, "Effect of perforated twisted-tapes with parallel wings on heat transfer enhancement in a heat exchanger tube", Energy Procedia, 14: 1117-1123

[12] Cengel, Y.A., Heat and Mass Transfer, $5^{\text {th }}$ edition McGraw-Hill, 2008 (Chapter 8).

[13] Webb, R.L., 1981, "Performance evaluation criteria for use of enhanced heat transfer surfaces in heat exchanger design”, International Journal of Heat and Mass Transfer, 24: 715-726. 